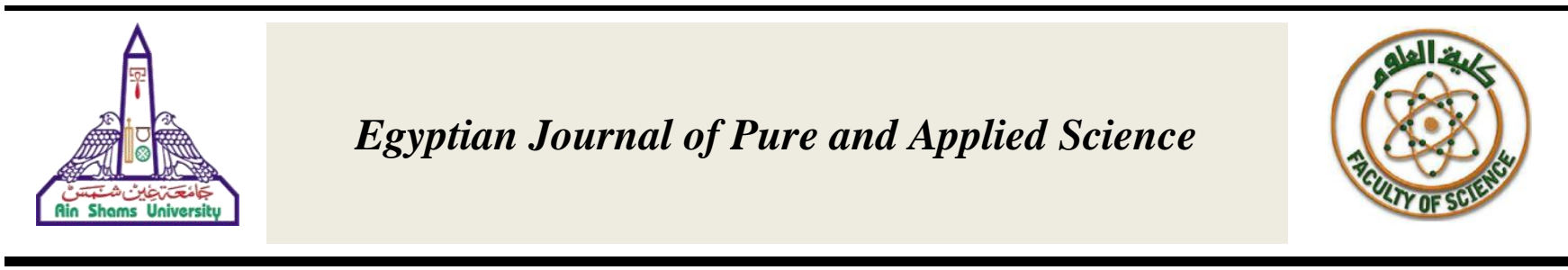

\title{
Hepatoprotective, therapeutic and in vitro cytotoxic activities of dandelion in comparison with silymarin
}

\author{
Mostafa M. Elhady and Nahla S. Hassan* \\ Department of Biochemistry, Faculty of Science, Ain Shams University, Cairo, Egypt
}

A R T I C L E IN F O

Article history:

Received 28 October 2014

Accepted 16 December 2014

Keywords:

Hepatoprotective;

Dandelion;

Silymarin:

Cytotoxicity;

HepG2.

\begin{abstract}
A B S T R A C T
Taraxacum officinale, or dandelion, has been used in folk medicine in the treatment of several diseases. The aim of this study is to evaluate the hepatoprotective effects of dandelion extract in comparison to silymarin both in vivo and in vitro. Sixty rats were divided into six groups, G1: normal control group, G2: liver injured rats induced by carbon tetrachloride $\left(\mathrm{CCl}_{4}\right), \mathrm{G} 3$ : rats protected by dandelion extract, G4: rats protected by silymarin extract, G5: rats treated with dandelion extract, G6: rats treated with silymarin extract To some extent, dandelion and silymarin were equally effective in reducing serum markers of liver damage as well as oxidative stress. Histopathological examination of liver sections confirmed these results. The two compounds showed cytotoxic activity on HepG2. Dandelion exerts an effective hepatoprotective property in experimental liver injury to a significant degree as standards of silymarin.
\end{abstract}

\section{Introduction}

The liver plays a pivotal role in the metabolism and detoxification of endogenous and exogenous hepatotoxicants in the body, and these metabolic reactions can also potentially lead to liver injury.

Carbon tetrachloride $\left(\mathrm{CCl}_{4}\right)$ is a widely used industrial solvent and it is a xenobiotic that can induce liver injury. It has been widely used in terrestrial animal models to investigate hepatotoxicity ${ }^{[1]}$. The most remarkable pathological characteristics of $\mathrm{CCl}_{4}$-induced hepatotoxicity are fatty liver, cirrhosis, and necrosis, which have been thought to result from the formation of reactive intermediates such as trichloromethyl radical $\left(\cdot \mathrm{CCl}_{3}\right)$ and trichloromethylperoxy radical $\left(\cdot \mathrm{OOCCl}_{3}\right)$ ${ }^{[2]}$.These free radicals lead to the peroxidation of fatty acids found in the phospholipids making up the cell membranes. Consequently, cell membrane structures and intracellular organelle membrane structures are completely broken down and finally induce corresponding health problems ${ }^{[3]}$.

The general strategy for prevention and treatment of liver damage; includes reducing the production of reactive metabolites and inhibiting the generation of free radicals using antioxidants ${ }^{[4]}$.

In recent years, with the speeding up of the rhythm of lifestyles and changing diets, the risk of liver disease has been increased greatly and is frequently fatal. Several

\footnotetext{
* Corresponding author.

E-mail address: nana_samir@hotmail.com
}

hepatoprotective agents have been applied in clinical practice, but some of them have potential adverse effects. On this basis, the use of natural antioxidant phytochemicals has surfaced as an effective and safe dietary reference for liver diseases ${ }^{[5]}$.

Common dandelion (Taraxacum officinale, Asteraceae), a widely distributed perennial weed in the Northern Hemisphere, has been used in folklore to treat diverse ailments such as dyspepsia, heartburn, spleen disorders and liver disorders ${ }^{[6]}$. Dandelion leaf is clinically used in various preparations, including infusions and ethanolic extracts and is added to salads because of its significant source of potassium, vitamins, and minerals. Dried dandelion leaves and roots are also available as herbal teas ${ }^{[7]}$.

Flavonoids and phenolic compounds (such as luteolin, caffeic acid, and chlorogenic acid) have been detected in extracts of dandelion. These compounds, which are generally found in plants, have been reported to protect cells from oxidative stress by preventing the formation of free radicals or by detoxifying free radicals, resulting in the protection from a variety of pathophysiological processes ${ }^{[8]}$.

Since common dandelion is often used as herbal tea, this study used dandelion hot water extract (DWE). Hence, the protective effects of DWE were evaluated in rats treated with $\mathrm{CCl}_{4}$. Silymarin, a natural hepatoprotective agent, was included as a reference control standard. 


\section{Materials and methods Materials:}

Dandelion and silymarin extracts were kindly provided as a gift sample from Egypharmaceutical company, Egypt. All chemicals used in this study were purchased from Sigma Chemical Co.(St. Louis, MO, USA) and Merck (Darmstadt, Germany). All other reagents kits were obtained from Biodiagnostic Company.

Dandelion, was dissolved in sterile $\mathrm{H}_{2} \mathrm{O}(100 \mathrm{mg} / \mathrm{ml})$ at room temperature for $2 \mathrm{~h}$ and then extracted twice with water at $100^{\circ} \mathrm{C}$ for $1 \mathrm{~h}$. The aqueous extracts were filtered through a $0.45 \mu \mathrm{m}$ membrane. This aqueous dandelion extract lyophilized and the resulting light yellow powder $(17 \% \mathrm{w} / \mathrm{w} \text { yield })^{[9]}$. The hot-water extract of silymarin was prepared by boiling with distilled water for $1 \mathrm{~h}$. The extract was filtered, freezedried, and kept at $4 \circ \mathrm{C}$. The yield of extraction was $16.73 \%{ }^{[10]}$.

\section{Animals:}

Sixty adult male rats were obtained from the Egyptian Company for vaccines \& medicines (center to produce natural toxin, Helwan farm). Rats were acclimated to the experimental facility for 1 week and housed in stainless steel cages ( $12 \mathrm{~h}$ dark/light cycle) an ambient temperature of $25^{\circ} \mathrm{C}$ and relative humidity of $55 \%$. Animal care was followed as recommended by the Committee for the Purpose of Control and Supervision of Experiments on Animals (CPCSEA).

\section{Induction of liver injury by $\mathrm{CCl}_{4}$ :}

Liver injury was induced according to the method of Bhadauria et al. ${ }^{[11]}$ with slight modifications. Rats were injected intraperitoneally with freshly prepared $\mathrm{CCl}_{4}$ in olive oil $(1: 1 \mathrm{~V} / \mathrm{V}, 2 \mathrm{ml} / \mathrm{kg})$ twice weekly for one week.

\section{Study design:}

Rats were randomly assorted into six groups: G1)rats were injected with olive oil and served as normal controls; G2) rats were intoxicated by $\mathrm{CCl}_{4}$ and served as positive controls; G3) rats received dandelion extract (25 $\mathrm{mg} / \mathrm{kg}$ daily) ${ }^{[\mathbf{6}, 12]}$ orally, for two weeks and then intoxicated with $\left.\mathrm{CCl}_{4} ; \mathrm{G} 4\right)$ rats received silymarin extract $\left(50 \mathrm{mg} / \mathrm{kg}\right.$ daily) ${ }^{[13,14]}$ orally, for two weeks and then intoxicated with $\mathrm{CCl}_{4}$; G5) $\mathrm{CCl}_{4}$ intoxicated rats treated with dandelion extract for two weeks; and G6) $\mathrm{CCl}_{4}$ intoxicated rats treated with silymarin extract for two weeks.

\section{Samples collection:}

At the end of the experiment, blood samples were taken by heart puncture under light ether anesthesia after a fast of $12 \mathrm{~h}$. Serum was separated from the clotted blood samples by centrifugation at $5000 \mathrm{rpm}$ for $5 \mathrm{~min}$ and then aliquot and analyzed. The liver was dissected out, rinsed in isotonic sterile saline, blotted dry on a filter paper, and a small part from the right lobe of the liver was cut and fixed in $10 \%$ buffered formalin $(\mathrm{pH} \mathrm{7.2)} \mathrm{at}$ $4^{\circ} \mathrm{C}$ for histologic examination.

\section{Preparation of liver homogenate:}

Twenty percent whole liver homogenate was prepared in phosphate buffered saline ( $\mathrm{pH}$ 7.4). Malondialdehyde (MDA) content, total protein, DNA and RNA concen- trations were estimated in the prepared homogenate. The MDA content was estimated according to method of Esterbauer and Cheesman ${ }^{[15]}$. Total protein concentration was estimated in the whole tissue homogenates by the dye binding method of Bradford ${ }^{[16]}$. Total DNA and RNA concentrations were extracted from the whole tissue homogenate by $5 \%$ perchloric acid according to the method of Schneider ${ }^{[17]}$ and then determined colorimetrically by the diphenylamine ${ }^{[\mathbf{1 8}]}$ and orcinol ${ }^{[19]}$ methods, respectively.

\section{Biochemical assays:}

Serum alanine and aspartate aminotransferase activities were determined by the colorimetric method of Reitman and Frankel ${ }^{[20]}$. Alkaline phosphatase (ALP) activity was determined by the colorimetric method of Kind and King ${ }^{[21]}$. Bilirubin was estimated according to the methodof Jacobsen ${ }^{[22]}$. $5^{\prime}$ nucleotidase (5' NT) activity was measured according to the method of Ellis and Goldberg ${ }^{[23]}$. Hydroxyproline contents were estimated in the blood samples by the methods of Domitrovi'c et al. ${ }^{[24]}$. Total protein concentration was estimated using the method of Bradford ${ }^{[16]}$. Serum albumin was colorimetrically determined using a commercial assay kit by the method of Doumaset $\boldsymbol{e t}$ al. [25]

\section{Histopathological examination:}

Specimens were cleared in xylene and embedded in paraffin at 56 degree in hot air oven for twenty four hours. Paraffin bees wax tissue blocks were prepared for sectioning at 4 microns by slidge microtome. The obtained tissue sections were collected on glass slides, deparaffinized and stained by hematoxylin and eosin stains ${ }^{[26]}$ for histopathological examination under a light microscope.

\section{Cytotoxic activity:}

In vitro cytotoxic potentialities of dandelion and silymarin were carried out on liver cancer cells (Hep G2) according to method of Skehan et al. ${ }^{[27]}$. Cells were plated in 96-multiwell plate for 24 hours before treatment with the tested extracts, to allow attachment of cell to the wall of the plate. Different concentrations of the tested $(0-100 \mu \mathrm{g} / \mathrm{ml})$ extracts were added to the cell monolayer. Triplicate wells were prepared for each individual dose. Monolayer cells were incubated with the extracts for 48 hours at $37^{\circ} \mathrm{C}$ in $5 \% \quad \mathrm{CO}_{2}$ atmosphere. After 48 hours, cells were fixed, washed and stained with sulforhodamine B (SRB) stain. Excess stain was washed with acetic acid and attached stain was recovered with Tris EDTA buffer. Color intensity was measured in an ELISA reader at $\lambda \max 564 \mathrm{~nm}$. The relation between surviving fraction and extract concentration was plotted to get the survival curve of the tumor cell line. Also, the $\mathrm{IC}_{50}$ for each tested extracts was calculated.

\section{Statistical analysis:}

Data were expressed as mean \pm standard deviation. Results of biochemical studies were statistically analyzed using one-way analysis of variance (ANOVA). All statistics were done using SPSS 17 for 
Windows (PSS, Inc., Chicago, IL, USA). Differences were considered statistically significant at $\mathrm{P}<0.05$.

\section{Results}

Results presented in Tables 1-3 and Figures 1 and 2 showed that, carbon tetrachloride intoxication in G2 caused a dramatic increase in serum conjugated bilirubin (120\%), ALT (244.3\%), AST (190.4\%), 5' NT (123.5 $\%)$, and ALP (60.6\%) activities compared with normal rats. With regard to their concentrations in normal control group, serum levels of total protein, and albumin were significantly decreased in $\mathrm{CCl}_{4}$ intoxicated rats by $41.7 \%$, and $47.5 \%$, respectively. In contrast, serum level of hydroxyproline was significantly increased when compared with its level in normal control group ( $\mathrm{p}<$ 0.001).

Prophylactic administration of dandelion (G3) caused a decrease in conjugated bilirubin (15.6\%), ALT (15.1\%), AST (4.1\%), 5' NT (22.2\%), and ALP (10\%) activities compared with $\mathrm{CCl}_{4}$ intoxicated rats (Table 1). In the meantime, pretreatment by dandelion impact positively on total protein, and albumin levels where dandelion increase those levels by $21 \%$ and $26.9 \%$ respectively as compared to positive control. Oral administration of dandelion before $\mathrm{CCl}_{4}$ intoxication caused nonsignificant decrease in hydroxyproline level.

Implemented dose of silymarin before intoxication (G4) caused marked reduction in serum levels of conjugated bilirubin, ALT, AST, 5' NT, and ALP when compared with those levels of positive control rats in G2. Silymarin administration has precautionary activity where, it elevates serum levels of total protein, and albumin when compared to positive control as received before hepatic injury. Pretreatment by silymarin exhibited significant reduction in hydroxyproline level (32.3\%) when compared with its level in positive control group.

The oral treatment of intoxicated rats with dandelion (G5) significantly improve the serum levels of conjugated bilirubin, ALT, AST, 5' NT, and ALP by 40.2 $\%, 64.5 \%, 58.9 \%, 39.2 \%$ and $25.7 \%$, respectively. Sequential administration of dandelion extract and $\mathrm{CCl}_{4}$ to rats restored serum protein fractions to normal levels. The same approach in normalization was observed in the serum hydroxyproline which markedly decreased by $49 \%$ when compared with positive control rats (Table 2).

Therapeutic administration of silymarin in liver injured rats (G6) improved the averages of conjugated bilirubin, ALT, AST, 5' NT, and ALP when compared with positive control. Remedial dose of silymarin also, optimized serum levels of total protein and albumin to normal levels by $68.5 \%$ and $60.9 \%$ respectively as compared to positive control. In the same context, significant decrease in hydroxyproline level $(p<0.001)$ was observed in silymarin treatment group.

Table 1: Effect of silymarin and dandelion extracts on serum liver enzymes in different rat groups.

\begin{tabular}{|c|c|c|c|c|}
\hline Groups & $\begin{array}{l}\mathbf{A L T} \\
(\mathbf{U} / \mathbf{L})\end{array}$ & $\begin{array}{c}\text { AST } \\
(\mathbf{U} / \mathbf{L}) \\
\end{array}$ & $\begin{array}{l}5^{\prime} \mathbf{N T} \\
(\mathrm{U} / \mathrm{L})\end{array}$ & $\begin{array}{c}\text { ALP } \\
(\mathbf{U} / \mathbf{L})\end{array}$ \\
\hline $\begin{array}{l}\text { Group } 1 \\
\text { Mean } \pm \text { S.D. }\end{array}$ & $35.38 \pm 2.09^{b}$ & $52.05 \pm 2.16^{\mathrm{b}}$ & $14.43 \pm 1.40$ & $114.17 \pm 6.76$ \\
\hline $\begin{array}{l}\text { Group } 2 \\
\text { Mean } \pm \text { S.D } \\
\quad \% \text { change \# G1 }\end{array}$ & $\begin{array}{c}121.83 \pm 20.13^{\mathrm{a}} \\
244.3 \%\end{array}$ & $\begin{array}{c}151.16 \pm 19.32^{\mathrm{a}} \\
190.4 \%\end{array}$ & $\begin{array}{c}32.25 \pm 4.46^{\mathrm{a}, \mathrm{b}} \\
123.5 \%\end{array}$ & $\begin{array}{c}183.37 \pm 19.63^{\mathrm{a}, \mathrm{b}} \\
60.6 \%\end{array}$ \\
\hline $\begin{array}{l}\text { Group } 3 \\
\text { Mean } \pm \text { S.D. } \\
\% \text { change \# G1 } \\
\% \text { change \# G2 }\end{array}$ & $\begin{array}{c}103.37 \pm 10.76^{\mathrm{a}, \mathrm{b}} \\
192.1 \% \\
15.1 \% \\
\end{array}$ & $\begin{array}{c}145.01 \pm 26.9^{\mathrm{a}} \\
178.6 \% \\
4.1 \% \\
\end{array}$ & $\begin{array}{c}25.10 \pm 5.24^{\mathrm{a}, \mathrm{b}} \\
73.9 \% \\
22.2 \% \\
\end{array}$ & $\begin{array}{c}165.01 \pm 19.92^{\mathrm{a}, \mathrm{b}} \\
44.5 \% \\
10.0 \%\end{array}$ \\
\hline $\begin{array}{l}\text { Group } 4 \\
\text { Mean } \pm \text { S.D. } \\
\quad \% \text { change \# G1 } \\
\% \text { change \# G2 }\end{array}$ & $\begin{array}{c}47.18 \pm 5.10^{\mathrm{a}, \mathrm{b}} \\
33.35 \% \\
61.3 \%\end{array}$ & $\begin{array}{c}72.42 \pm 7.10^{\mathrm{a}, \mathrm{b}} \\
39.1 \% \\
52.1 \%\end{array}$ & $\begin{array}{c}17.27 \pm 1.65^{b} \\
19.7 \% \\
46.4 \%\end{array}$ & $\begin{array}{c}155.94 \pm 14.40^{\mathrm{a}, \mathrm{b}} \\
36.6 \% \\
14.9 \%\end{array}$ \\
\hline $\begin{array}{l}\text { Group } 5 \\
\text { Mean } \pm \text { S.D. } \\
\% \text { change \# G1 } \\
\% \text { change \# G2 }\end{array}$ & $\begin{array}{c}43.31 \pm 5.91^{b} \\
22.4 \% \\
64.5 \% \\
\end{array}$ & $\begin{array}{c}62.01 \pm 5.13^{b} \\
19.13 \% \\
58.9 \% \\
\end{array}$ & $\begin{array}{c}19.60 \pm 3.59^{\mathrm{a}, \mathrm{b}} \\
35.8 \% \\
39.2 \% \\
\end{array}$ & $\begin{array}{c}136.31 \pm 3.91^{\mathrm{a}, \mathrm{b}} \\
19.4 \% \\
25.7 \% \\
\end{array}$ \\
\hline $\begin{array}{l}\text { Group } 6 \\
\text { Mean } \pm \text { S.D. } \\
\% \text { change \# G1 } \\
\% \text { change \# G2 }\end{array}$ & $\begin{array}{c}40.42 \pm 5.05^{\mathrm{b}} \\
14.25 \% \\
66.8 \% \\
\end{array}$ & $\begin{array}{c}58.81 \pm 8.74^{b} \\
12.9 \% \\
61.1 \% \\
\end{array}$ & $\begin{array}{c}18.07 \pm 3.24^{\mathrm{b}} \\
25.2 \% \\
43.9 \% \\
\end{array}$ & $\begin{array}{c}124.8 \pm 11.84^{\mathrm{b}} \\
9.3 \% \\
31.9 \% \\
\end{array}$ \\
\hline
\end{tabular}

Values are mean \pm SD for 10 animals in each group.

a: Significant difference at $\mathrm{p}<0.05$ compared with control group $(\mathrm{G} 1)$.

b: Significant difference at $\mathrm{p}<0.05$ compared with $\mathrm{CCl}_{4}$ treated animals $(\mathrm{G} 2)$.

ALT: alanine transferase; AST: aspartate transferase; 5' NT: 5' nucleotidase; ALP: alkaline phosphatase. 
Table 2: Effect of silymarin and dandelion extracts on serum direct bilirubin,hydroxyproline,total proteins and albumin) in different rat groups.

\begin{tabular}{|c|c|c|c|c|}
\hline Groups & $\begin{array}{c}\text { DB } \\
(\mathrm{mg} \%)\end{array}$ & $\begin{array}{c}\text { HYP } \\
(\mathrm{mg} \%)\end{array}$ & $\begin{array}{c}\mathbf{T P} \\
(\mathrm{g} \%)\end{array}$ & $\begin{array}{c}\text { Alb } \\
(\mathrm{g} \%)\end{array}$ \\
\hline $\begin{array}{l}\text { Group } 1 \\
\text { Mean } \pm \text { S.D. }\end{array}$ & $0.35 \pm 0.07^{b}$ & $1.02 \pm 0.29^{b}$ & $7.51 \pm 0.90^{b}$ & $3.75 \pm 0.51^{\mathrm{b}}$ \\
\hline $\begin{array}{l}\text { Group } 2 \\
\text { Mean } \pm \text { S.D } \\
\% \text { change \# G1 }\end{array}$ & $\begin{array}{c}0.77 \pm 0.07^{\mathrm{a}} \\
120 \%\end{array}$ & $\begin{array}{c}2.57 \pm 0.46^{\mathrm{a}} \\
151.9 \%\end{array}$ & $\begin{array}{c}4.38 \pm 0.87^{\mathrm{a}} \\
41.7 \%\end{array}$ & $\begin{array}{c}1.97 \pm 0.54^{\mathrm{a}} \\
47.5 \%\end{array}$ \\
\hline $\begin{array}{l}\text { Group } 3 \\
\text { Mean } \pm \text { S.D. } \\
\% \text { change \# G1 } \\
\% \text { change \# G2 }\end{array}$ & $\begin{array}{c}0.65 \pm 0.19^{\mathrm{a}} \\
85.7 \% \\
15.6 \%\end{array}$ & $\begin{array}{c}2.34 \pm 0.82^{\mathrm{a}} \\
129.4 \% \\
8.9 \%\end{array}$ & $\begin{array}{c}5.30 \pm 0.77^{\mathrm{a}} \\
29.4 \% \\
21.0 \%\end{array}$ & $\begin{array}{c}2.50 \pm 0.43^{\mathrm{a}} \\
33.3 \% \\
26.9 \%\end{array}$ \\
\hline $\begin{array}{l}\text { Group } 4 \\
\text { Mean } \pm \text { S.D. } \\
\% \text { change \# G1 } \\
\% \text { change \# G2 }\end{array}$ & $\begin{array}{c}0.49 \pm 0.09^{\mathrm{a}, \mathrm{b}} \\
40.0 \% \\
36.4 \%\end{array}$ & $\begin{array}{c}1.74 \pm 0.74^{\mathrm{a}, \mathrm{b}} \\
70.6 \% \\
32.3 \%\end{array}$ & $\begin{array}{c}6.98 \pm 0.95^{b} \\
7.1 \% \\
59.3 \%\end{array}$ & $\begin{array}{c}3.07 \pm 0.50^{\mathrm{a}, \mathrm{b}} \\
18.1 \% \\
55.8 \%\end{array}$ \\
\hline $\begin{array}{l}\text { Group } 5 \\
\text { Mean } \pm \text { S.D. } \\
\% \text { change \# G1 } \\
\% \text { change \# G2 }\end{array}$ & $\begin{array}{c}0.46 \pm 0.09^{\mathrm{a}, \mathrm{b}} \\
31.4 \% \\
40.2 \%\end{array}$ & $\begin{array}{c}1.31 \pm 0.19^{b} \\
28.4 \% \\
49.0 \%\end{array}$ & $\begin{array}{c}6.16 \pm 1.04^{\mathrm{a}, \mathrm{b}} \\
17.9 \% \\
40.6 \%\end{array}$ & $\begin{array}{c}2.65 \pm 0.73^{\mathrm{a}, \mathrm{b}} \\
29.3 \% \\
34.5 \%\end{array}$ \\
\hline $\begin{array}{l}\text { Group } 6 \\
\text { Mean } \pm \text { S.D. } \\
\% \text { change \# G1 } \\
\% \text { change \# G2 }\end{array}$ & $\begin{array}{c}0.41 \pm 0.10^{b} \\
17.1 \% \\
46.7 \%\end{array}$ & $\begin{array}{c}1.17 \pm 0.32^{b} \\
14.7 \% \\
54.5 \%\end{array}$ & $\begin{array}{c}7.38 \pm 0.57^{b} \\
1.7 \% \\
68.5 \%\end{array}$ & $\begin{array}{c}3.17 \pm 0.54^{b} \\
15.5 \% \\
60.9 \%\end{array}$ \\
\hline
\end{tabular}

Values are mean $\pm \mathrm{SD}$ for 10 animals in each group.

a: Significant difference at $\mathrm{p}<0.05$ compared with control group (G1).

b: Significant difference at $p<0.05$ compared with $\mathrm{CCl}_{4}$ treated animals $(\mathrm{G} 2)$.

DB: direct bilirubin; TP: total proteins; HYP: hydroxyproline; Alb: albumin.

$\mathrm{CCl}_{4}$ intoxication induced significant increases in hepatic MDA content (110.9\%); in contrast, significant decreases were recorded in total protein, RNA, and DNA concentrations $(60.7 \%, 54 \%$, and $68.1 \%$, respectively) compared with the normal control rats. All of the aforementioned parameters were slightly normalized in the rest groups that receiving silymarin and dandelion pre or post hepatic injury by $\mathrm{CCl}_{4}$ (Table 3).

Histologic examination of liver sections from all rats is presented in Figure 1, showed liver section of healthy control rats with normal hepatic lobular architecture, showing structural integrity (Fig. 1a). On the contrary, liver sections of $\mathrm{CCl}_{4}$ intoxicated rats (Fig.1b) showed ballooning degeneration of hepatocytes with foci of dysplasia with steatosis. Bile duct damage and infiltration by chronic inflammatory cells were also seen. Conversely, liver sections of the dandelion protective group (G3) showed nodules that vary in size in which there are many lymphocytes and plasma cells (Fig. 1c). In the meantime, Liver sections of the prophylactic group with silymarin (G4) showed minimal parenchymal spotty inflammation and mild portal tract inflammation (Fig. 1d). In contrast, Liver sections of the curative group supplemented by dandelion (G5) showed the mature fibrous tissue (Fig. 1e). While, liver sections of the therapeutic group treated with silymarin (G6) showed very mild parenchymal and very mild portal tract inflammation (Fig. 1f).

The investigated cytotoxic activity of the tested extracts against HepG2 cell lines showed dose-dependent reduction of the $\mathrm{IC}_{50}$ values by $38.04 \mu \mathrm{g}$ and $12.84 \mu \mathrm{g}$ for dandelion and silymarin, respectively (Fig. 2).

\section{Discussion}

In the present study, the hepatoprotective and therapeutic effects of dandelion and silymarin extracts were investigated against $\mathrm{CCl}_{4}$-induced hepatotoxicity in rats. $\mathrm{CCl}_{4}$ is considered a potent hepatotoxin, which is frequently used to produce an experimental model to study the mechanisms involved in the progression of hepatic disease and the impact of various drugs on this progression. $\mathrm{CCl}_{4}$ induces cytotoxic injury through bioactivation mediated by the microsomal cytochrome P450 isozyme to trichloromethyl radical and further to a reactive metabolite. These activated radicals bind covalently to the macro-molecules and induce peroxidative degradation of membrane lipids of endoplasmic reticulum, which is rich in polyunsaturated fatty acids. This leads to the formation of lipid peroxides $[28,29]$

One of the most sensitive indicators of hepatocyte injury is the release of intracellular enzymes in the circulation. There is a direct correlation between rise in these serum enzyme activities and severity of damage to liver tissue [30] 
Table 3: Effect of silymarin and dandelion extracts on hepatic biochemical parameters in different rat groups.

\begin{tabular}{|c|c|c|c|c|}
\hline Groups & $\begin{array}{c}\text { MDA } \\
(\mathrm{nmol} / \mathrm{g})\end{array}$ & $\begin{array}{c}\text { TP } \\
(\mathrm{mg} / \mathrm{g})\end{array}$ & $\begin{array}{c}\text { RNA } \\
(\mathrm{mg} / \mathrm{g})\end{array}$ & $\begin{array}{c}\text { DNA } \\
(\mathrm{mg} / \mathrm{g})\end{array}$ \\
\hline $\begin{array}{l}\text { Group } 1 \\
\text { Mean } \pm \text { S.D. }\end{array}$ & $21.25 \pm 1.47^{\mathrm{b}}$ & $153.9 \pm 24.21^{b}$ & $6.93 \pm 0.38^{b}$ & $3.10 \pm 0.27^{b}$ \\
\hline $\begin{array}{l}\text { Group } 2 \\
\text { Mean } \pm \text { S.D } \\
\quad \% \text { change \# G1 }\end{array}$ & $\begin{array}{c}44.82 \pm 6.23^{\mathrm{a}} \\
110.9 \%\end{array}$ & $\begin{array}{l}60.41 \pm 4.75^{\mathrm{a}} \\
60.7 \%\end{array}$ & $\begin{array}{c}3.17 \pm 0.41^{\mathrm{a}} \\
54.0 \%\end{array}$ & $\begin{array}{c}0.99 \pm 0.33^{\mathrm{a}} \\
68.1 \%\end{array}$ \\
\hline $\begin{array}{l}\text { Group } 3 \\
\text { Mean } \pm \text { S.D. } \\
\% \text { change \# G1 } \\
\% \text { change \# G2 }\end{array}$ & $\begin{array}{c}39.23 \pm 5.44^{\mathrm{a}, \mathrm{b}} \\
84.6 \% \\
12.5 \%\end{array}$ & $\begin{array}{c}76.82 \pm 4.32^{\mathrm{a}, \mathrm{b}} \\
50.1 \% \\
27.1 \%\end{array}$ & $\begin{array}{c}3.75 \pm 0.14^{\mathrm{a}, \mathrm{b}} \\
45.6 \% \\
18.3 \%\end{array}$ & $\begin{array}{c}1.35 \pm 0.09^{\mathrm{a}, \mathrm{b}} \\
56.4 \% \\
36.3 \%\end{array}$ \\
\hline $\begin{array}{l}\text { Group } 4 \\
\text { Mean } \pm \text { S.D. } \\
\% \text { change \# G1 } \\
\% \text { change \# G2 }\end{array}$ & $\begin{array}{c}32.94 \pm 5.86^{\mathrm{a}, \mathrm{b}} \\
55 \% \\
26.5 \%\end{array}$ & $\begin{array}{c}88.42 \pm 9.74^{\mathrm{a}, \mathrm{b}} \\
42.5 \% \\
46.3 \%\end{array}$ & $\begin{array}{c}4.09 \pm 0.23^{\mathrm{a}, \mathrm{b}} \\
40.7 \% \\
29.0 \%\end{array}$ & $\begin{array}{c}1.73 \pm 0.32^{\mathrm{a}, \mathrm{b}} \\
44.2 \% \\
74.7 \%\end{array}$ \\
\hline $\begin{array}{l}\text { Group } 5 \\
\text { Mean } \pm \text { S.D. } \\
\% \text { change \# G1 } \\
\% \text { change \# G2 }\end{array}$ & $\begin{array}{c}27.16 \pm 1.51^{\mathrm{a}, \mathrm{b}} \\
27.8 \% \\
39.4 \%\end{array}$ & $\begin{array}{c}95.70 \pm 10.15^{\mathrm{a}, \mathrm{b}} \\
37.8 \% \\
58.4 \%\end{array}$ & $\begin{array}{c}4.32 \pm 0.18 \\
37.4 \% \\
36.3 \%\end{array}$ & $\begin{array}{c}2.01 \pm 0.40^{\mathrm{a}, \mathrm{b}} \\
35.1 \% \\
103 \%\end{array}$ \\
\hline $\begin{array}{l}\text { Group } 6 \\
\text { Mean } \pm \text { S.D. } \\
\% \text { change \# G1 } \\
\% \text { change \# G2 }\end{array}$ & $\begin{array}{c}23.51 \pm 3.10^{\mathrm{a}, \mathrm{b}} \\
10.6 \% \\
47.5 \%\end{array}$ & $\begin{array}{c}124.54 \pm 12.43^{\mathrm{a}, \mathrm{b}} \\
19.1 \% \\
106.1 \%\end{array}$ & $\begin{array}{c}4.87 \pm 0.61^{\mathrm{a}, \mathrm{b}} \\
29.4 \% \\
53.6 \%\end{array}$ & $\begin{array}{c}2.97 \pm 0.25^{\mathrm{a}, \mathrm{b}} \\
4.2 \% \\
200 \%\end{array}$ \\
\hline
\end{tabular}

Values are mean \pm SD for 10 animals in each group.

a: Significant difference at $\mathrm{p}<0.05$ compared with control group (G1).

b: Significant difference at $\mathrm{p}<0.05$ compared with $\mathrm{CCl}_{4}$ treated animals $(\mathrm{G} 2)$.

MDA: malondialdehyde; TP: total proteins.

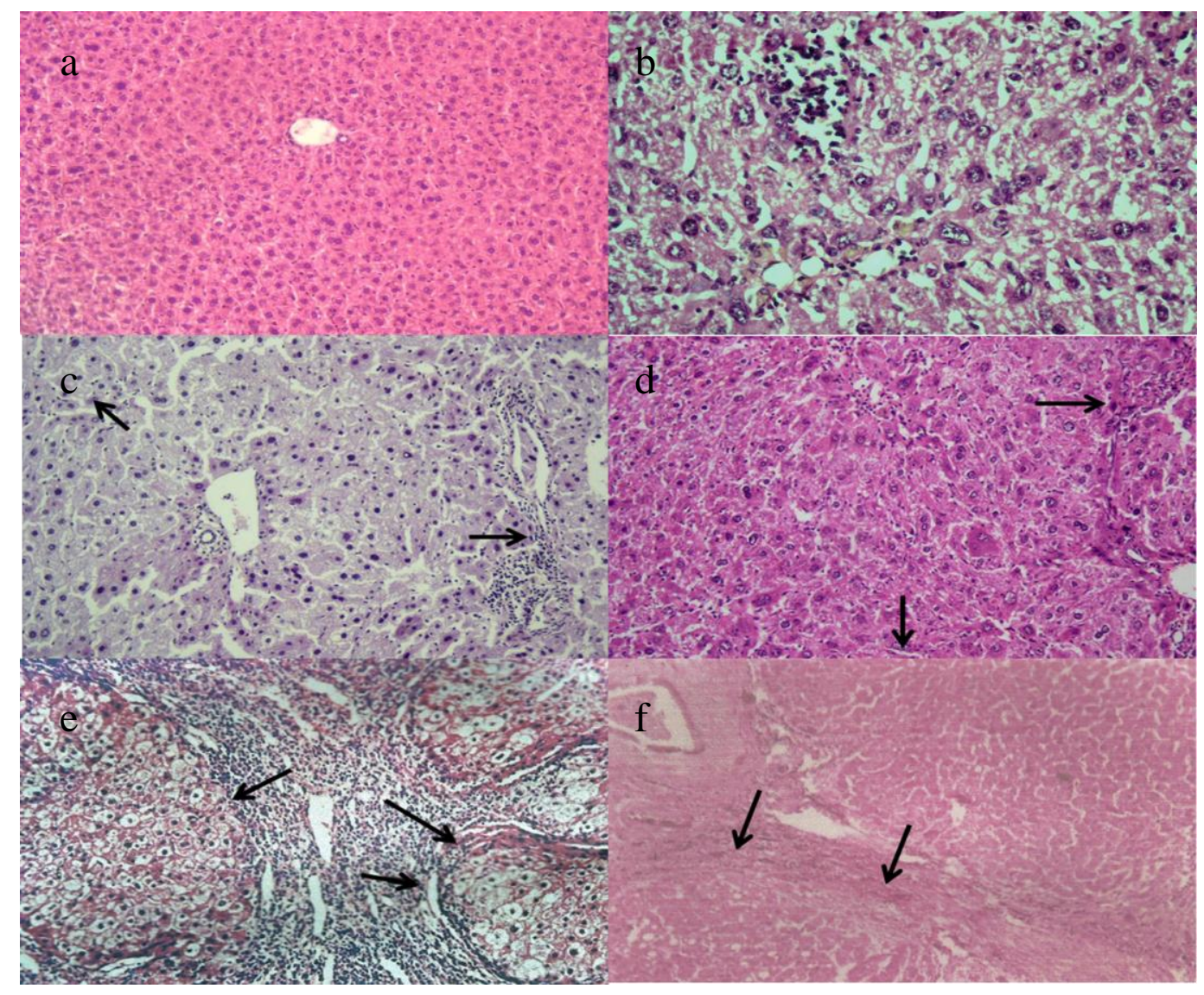

Fig. 1: Histopathological examination of liver tissues. (a) normal control, (b) positive control, (c) prophylactic group receiving silymarin, (d) therapeutic group receiving silymarin, (e) prophylactic group receiving dandelion and (f) therapeutic group receiving dandelion. 


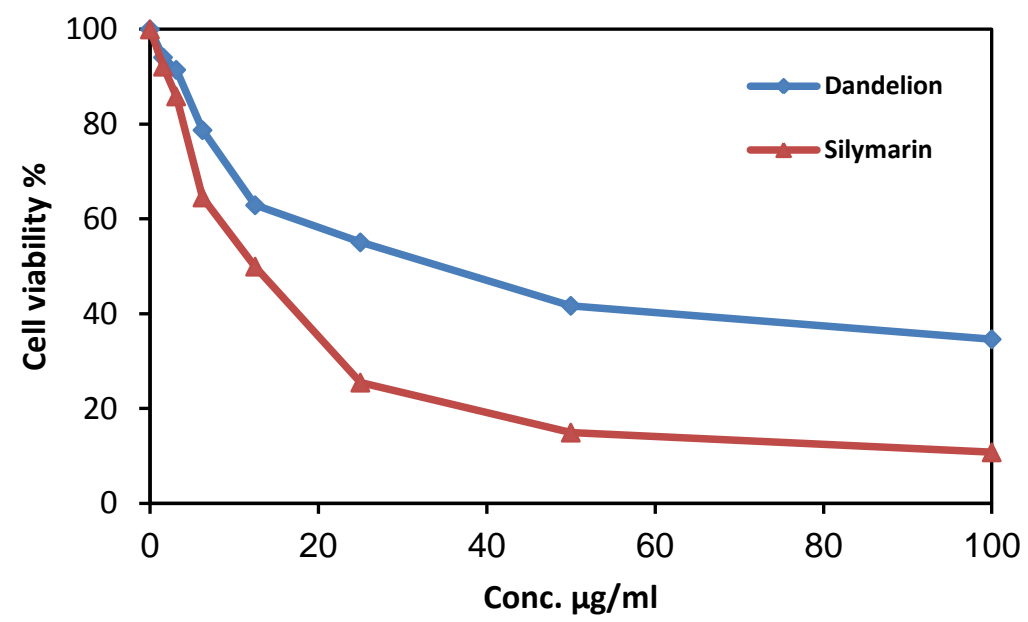

Fig. 2: Cytotoxic activity of silymarin and dandelion extracts against hepatocellular carcinoma (HepG2) cells.

Direct evidence of $\mathrm{CCl}_{4}$ hepatotoxicity was noted in the occurrence of marked increase in the level of serum conjugated bilirubin and also in ALT, AST and ALP activities. This dramatic increase provided evidence of intrahepatic biliary obstruction, which was confirmed by histopathological examination of liver sections. These results are in agreement with many findings ${ }^{[31,32]}$. Prophylactic administration of dandelion and silymarin substantially attenuated the hepatotoxic effect of $\mathrm{CCl}_{4}$ as evident by the normalization of serum bilirubin, ALT, AST and ALP activities. In addition, examination of liver sections showed slight alterations in the hepatocytes. On the same line, Therapeutic administration of dandelion and silymarin extracts improves the averages of the mentioned parameters but by greater extent. The hepatic improvement may be due to the prevention of the leakage of intracellular enzymes by stabilizing membrane activity.This is in agreement with Palanivel et al. ${ }^{[33]}$. The author reported that the healing of hepatic parenchyma and the regeneration of hepatocytes is implicated in liver improvement.

Several overviews have covered the multiple pathophysiological roles of 5'-nucleotidase. They reveal novel insight into its functional involvement in endothelial and fluid transport; endothelial barrier function; adaption to hypoxia and ischemic preconditioning; the cardiovascular system; lung, liver, and kidney function ${ }^{[34]}$; the airways ${ }^{[35]}$; immunity and inflammation ${ }^{[36]}$; leucocyte trafficking ${ }^{[37]}$; the nervous system ${ }^{[38]}$, including a novel role of 5'-nucleotidasein inhibiting nociception ${ }^{[39]}$; or the immune control of cancer ${ }^{[40]}$. 5'-nucleotidase is a component of the multiresistance machinery of tumor cells against immune surveillance and/or anticancer therapy ${ }^{[41]}$.

Forms of released 5'-nucleotidase may have different cellular origins. The serum form presumably is derived from the liver ${ }^{[42]}$. The elevation in its level in $\mathrm{CCl}_{4}$ intoxicated rats could be due to the hepatic fibrosis, where Peng et al. ${ }^{[43]}$ reported that extracellular forma- tion of adenosine by the action of 5'-nucleotidase plays a critical role in the development of hepatic fibrosis.

Since the metabolism of proteins, synthesis of amino acid and urea occurs in the liver; we anticipated alterations in the concentrations of these materials in liver disease. Presumably, these alterations are more marked in chronic conditions, as in liver cirrhosis. Reduced level of albumin usually follows the severity of the condition, and it is a reliable index of the prognosis ${ }^{[44]}$. Generally, the concentration of serum proteins can be used as a measurement of liver function, especially when they are compared with proteins that are not produced in the liver. $\mathrm{CCl}_{4}$ intoxication significantly decreased serum total protein and albumin concentrations. Comparable results

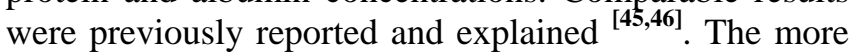
valuable observations in our study are the normalization of serum total protein, and albumin in different groups receiving dandelion or silymarin before or after liver injury by $\mathrm{CCl}_{4}$. these results are in matching with previous researches ${ }^{[14,47]}$. We suggest that, the hepatoprotective activities of the two extracts are due to their content of phenolic acids. Phenolic acids have been reported to induce phase II detoxifying enzymes, which suppress $\mathrm{CCl}_{4}$-active metabolites.

Liver fibrosis involves abnormal synthesis and the accumulation of extracellular matrix proteins, in particular collagen, in the liver parenchyma by activated hepatic stellate cells ${ }^{[48]}$. Matrix metalloproteinases (MMPs) comprise a family of zinc-dependent enzymes that specifically degrade extracellular matrix components like collagen. The activity of MMPs is regulated by tissue inhibitors of metalloproteinases (TIMPs). Sustained TIMPs expression is a key factor resulting in the progression of fibrosis ${ }^{[49]}$. TIMPs are produced by Kupffer cells, hepatic stellate cells and myofibroblasts in liver, but they are mainly produced by activated hepatic stellate cells. Injured liver tissue expresses more TIMP-1, which in turn causes interstitial fibrils to accumulate. Hydroxyproline is an amino acid unique to all collagens 
and its level reflects the amount of collagen present and therefore can be used to determine the extent of fibrosis [50]. $\mathrm{CCl}_{4}$ intoxication caused a dramatic increase in hepatic hydroxyproline content compared with normal controls, which was supported by the presence of fibrosis. Parallel findings have been reported previously [51]. Implemented prophylactic and therapeutic doses of dandelion and silymarin normalized the hepatic hydroxyproline content and decreased the liver fibrotic pattern.

The polyphenolic compounds, in the two extracts, have a high scavenging activity for free radicals and active oxygen species produced by $\mathrm{CCl}_{4}$ intoxication, thus suppressing hepatic stellate cells activation. Also, these results suggest that the anti-fibrotic effect of both dandelion and silymarin is related to increased removal of deposited collagen, that is, enhanced collagenolytic activity due to decreased TIMP-1 levels.

The estimation of MDA, a byproduct of peroxidation of biological membrane polyunsaturated fatty acids, is used as an indicator of oxidative stress ${ }^{[52]}$. The $\mathrm{CCl}_{4}$ intoxication induced an intense oxidative stress as evident by the increased hepatic MDA. Comparable findings have been reported previously ${ }^{[53]}$. The effect of the two extracts (in both protected and treated groups) on the suppression of free radicals is evident by the decreased MDA level.

The human body contains many molecules (lipids, DNA, protein, vitamins, and carbohydrates) that are susceptible to attack by reactive oxygen species, causing many human diseases. Antioxidants inhibit lipid peroxidation but may not protect other molecules, such as nucleic acids and protein, against oxidative damage. In the present study, the $\mathrm{CCl}_{4}$-induced oxidative stress caused significant decreases in liver DNA, RNA, and total protein concentrations. The significant decreased nucleic acids suggest that ROS produced by $\mathrm{CCl}_{4}$ intoxication caused tissue DNA oxidative damage. In the meantime, the significant decrease in hepatic total protein concentration might be due to hypertrophy of the liver, a smaller number of functioning hepatocytes owing to fibrosis, and fatty liver. In the protective and therapeutic groups, hepatic total protein, DNA, and RNA contents were normalized to lesser extent. The significant improvement at the level of biochemical parameters indicates the beneficial effects of the selected plant extract in protecting the liver.

Cancer-related research is conducted worldwide every day, since cancer is a leading cause of death. These studies often involve the investigation of the effects of biologically active substances on cancer cells, and they frequently originate from plants. There is a great need to examine reliable and inexhaustible sources of natural substances. In addition, it is important to understand the mechanisms of anticancer agents for future application in cancer therapy.

Consumption of foods that contain phenolics and flavonoids has been shown to reduce the risk of cancer $[\mathbf{5 4}, \mathbf{5 5}$. In addition, several studies have indicated high cytotoxic and anticancer activity of flavonoids ${ }^{[\mathbf{5 6}, 57]}$.
Dandelion and silymarin extracts shown cytotoxic activity on Hep G2 cells. The best cytotoxic activity was observed with silymarin $\left(\mathrm{IC}_{50}=12.84 \mu \mathrm{g}\right)$ when compared with dandelion which showed antiproliferative activity with $\mathrm{IC}_{50}=38.04 \mu \mathrm{g}$. The results indicate that, both dandelion and silymarin extracts are considered to be a particularly valuable source of effective anti-proliferative and cytotoxic substances that having anticancer activities may include inhibition of cell growth, inhibition of protein kinase activities, and induction of apoptosis.

In conclusion dandelion extract in comparison to silymarin extract to some extent exhibited significant hepatoprotective activity against $\mathrm{CCl}_{4}$ induced liver injury in rats, demonstrated by an amelioration of liver function tests and substantial improvement in the hepatocellular architecture. The hepatoprotection could be attributed to their contents; active phenolic compounds with antioxidant and antiproliferative activities. So we recommend that, dandelion could be used as a suitable alternative to silymarin as hepatoprotective agent or may be used in combination in the treatment of hepatocellular pathologies.

\section{Acknowledgments:}

The authors are thankful to Dr. Ahmed H. Ali, Faculty of medicine, Cairo University, for providing necessary facilities, valuable assistance and efforts to carry out histopathological examination. This work was done at the Department of Biochemistry, Faculty of Science, Ain Shams University, Cairo, Egypt.

\section{References}

1) Jia, R. I., Cao, L., Du, J., Xu, P., Jeney, G. and Yin, G. (2013). The protective effect of silymarin on the carbon tetrachloride $\left(\mathrm{CCl}_{4}\right)$-induced liver injury in common carp. In Vitro Cell Dev Biol Anim., 49(3):155-161.

2) Xia, D., Yongsheng, F., Zhang, P., Fu, Y., Mengting, J. and Xiaosa, Z. (2013). Protective effects of the flavonoid-rich fraction from rhizomes of Smilax glabra Roxb. on carbon tetrachlorideinduced hepatotoxicity in rats. J Membrane Biol., 246:479-485.

3) Cengiz, N., Kavak, S., Gu“zel, A., Ozbek, H., Bektas, H., Him, A., Erdog $\breve{a n, ~ E . ~ a n d ~}$ Balahoroglu, R. (2013). Investigation of the hepatoprotective effects of sesame (Sesamumindicum L) in carbon tetrachloride induced liver toxicity. $J$ Membrane Biol., 246:1-6.

4) Bansal, M., Kovalovich, K., Li, W., Gupta, R., Taub, R., Alvarez, C, Safadi, R., Radbill, B., Friedman, S. and Agarwarl, A. (2005). Interleukin6 protects hepatocytes from $\mathrm{CCl} 4$ - mediated necrosis and apoptosis in mice by reducing MMP-2 expression. Journal of Hepatology, 42:548-556.

5) Cui, Y., Han, Y., Yang, X., Yanfei, S. and Zhao, Y. (2014). Protective effects of quercetin and quercetin5', 8-disulfonate against carbon tetrachloride-caused oxidative liver injury in mice. Molecules, 19:291305. 
6) Park, C., Yeon, S., Hyun, J., Chung, W. and Young, S. (2011). Amelioration of oxidative stress by dandelion extract through CYP2E1 suppression against acute liver injury induced by carbon tetrachloride in sprague-dawley rats. Phytother. Res., 24:1347-1353.

7) Clare, B. A., Conroy, R. S. and Spelman, K. (2009). The diuretic effect in human subjects of an extract of Taraxacum officinale folium over a single day. J Altern Complement Med., 15(8):929-934.

8) Hu, C. and Kitts, D. (2005). Antioxidant, prooxidant, and cytotoxic activities of solventfractionated dandelion (Taraxacum officinale) flower extracts in vitro. J. Agric. Food Chem., 51:301-310.

9) He, W., Han, H., Wang, W. and Gao, B. (2011). Anti-influenza virus effect of aqueous extracts from dandelion. Virol. J., (14)8:538.

10) Duan, L., Wallace, S. N., Engelberth, A. et al., (2009). Extraction of co-products from biomass: example of thermal degradation of silymarin compounds in subcritical water. Applied Biochemistry and Biotechnology, 158(2): 362-373.

11) Bhadauria, M., Kumar, N., Shrivastava, S., Sharma, A., Johri, S., Chandan, K., Singh, B. and Sangeeta, S. (2009). Emodin reverses CCl4 induced hepatic cytochrome P450 (CYP) enzymatic and ultrastructural changes: The in vivo evidence. Hepatology Research, 39(3):290-300.

12) Modaresi, M. and Resalatpour, N. (2012). The effect of Taraxacum officinale hydroalcoholic extract on blood cells in mice. Adv Hematol., 2012:653412.

13) Alshawsh, M. A., Abdulla, M. A., Ismail, S. and Amin, Z. A. (2011). Hepatoprotective effects of Orthosiphonstamineus extract on thioacetamideinduced liver cirrhosis in rats. Evid Based Complement Alternat Med., 2011:103039.

14) Narayan, P., Anirban, P., Karuna, S., Dyaneshwar, U., Anil, K., Mahendra, P. and Suman, P. (2008). Synergistic effect of silymarine and standardized extract of Phyllanthusamarus against $\mathrm{CCl}_{4}$-induced hepatotoxicity in rats. Phytomedicine, 15:1053-1061.

15) Esterbauer, H. and Cheesman, K. (1990). Determination of aldehyde lipid peroxidation products: malondialdehyde and 4-hydroxynonenal. Method Enzymol., 86:407-410.

16) Bradford, M. (1976). A rapid and sensitive method for the quantitation of microgram quantities of protein utilizing the principle of protein dye binding. Anal Biochem., 72:248-254.

17) Schneider, W. (1945). Phosphorus compounds in animal tissues.1. Extraction and estimation of deoxypentose nucleic acid and of pentose nucleic acid. J Biol Chem., 161:293-303.

18) Dische, Z. and Schwartz, K. (1954). Estimation of nucleic acids. In: Glick D, editor. Methods of bioch- emical analysis. New York: Interscience Publishers; p. 299.

19) Dische, Z. (1957). Determination of pentoses. In: Colourick SP, Kaplan NO, editors. Methods in enzymology. New York: Academic Press; p.88.

20) Reitman, S. and Frankel, S. (1957). A colorimetric method for the determination of serum glutamic oxaloacetic and glutamic pyruvic transaminases. $A m$ J Clin Pathol., 28:56-63.

21) Kind, P. and King, E. (1954). Estimation of plasma phosphatase by determination of hydrolyzed phenol with antipyrine. J Clin Pathol., 7:322-326.

22) Jacobsen, J. and Wennberg, R. P. (1974). Determination of unbound bilirubin in the serum of newborns. Clin. Chem., 20:783-789.

23) Ellis, G. and Goldberg, M. (1972). Routine determination of $5^{\prime}$ nucleotidase. J Clin. Pathol., 25(10):907-909.

24) Domitrović, R., Jakovac, H., Tomac, J. and Sain, I. (2009). Liver fibrosis in mice induced by carbon tetrachloride and its reversion by luteolin. Toxicol Appl Pharmacol., 241(3):311-321.

25) Doumas, B., Watson, W. and Biggs, H. (1971). Albumin standards and the measurement of serum albumin with bromcresol green. Clin Chim Acta., 31(1):87-96.

26) Bancroft, J. D. and Gamble, M. (2002). Theory and practice of histological techniques. 5th Ed. Edinburgh. Churchill Livingstone Pub.

27) Skehen, P., Storage, R., Scudiero, D., Monks, A., McMahon, J., Vistica, D., Warren, J., Bokesch, H., Kenney, S. and Boyd, M. (1990). New colorimetric cytotoxicity assay for anti-cancer drug screening. J. Natl. Cancer Inst., 82(13):1107-1112.

28) Gutiérrez, M. and Solis V. (2009). Hepatoprotective and inhibition of oxidative stress in liver of Prostecheamichuacana. Rec. Nat. Prod., 3(1):46-51.

29) Noori, S., Rehman, N., Qureshi, M. and Mahboob, T. (2009). Reduction of Carbon TetrachlorideInduced Rat Liver Injury by Coffee and Green Tea. Pakistan Journal of Nutrition, 10:452-458.

30) Gowri, S., Manavalan, R., Venkappayya, D. and David, C. (2008). Hepatoprotective and antioxidant effects of Commiphoraberryi (Arn) Engl bark extract against $\mathrm{CCl}_{4}$-induced oxidative damage in rats. Food Chem Toxicol., 46(9):3182-3185.

31) Yokogawa, K., Watanabe, M., Takeshita, H., Nomura, M., Mano, Y. and Miyamoto, K. (2004). Serum aminotransferase activity as a predictor of clearance of drugs metabolized by CYP isoforms in rats with acute hepatic failure induced by carbon tetrachloride. Int J Pharm., 269(2):479-489.

32) Pradeep, H., Khan, S., Ravikumar, K., Fazil, A., Meesala, S., MandavaKiranmai, M., Dachani, S. and Shaik R. (2009). Hepatoprotective evaluation of Anogeissuslatifolia: in vitro and in vivo studies. World J Gastroenterol., 15(38):4816-4822. 
33) Palanivel, M., Rajkapoor, B., Senthil, K., Einstein, J., Kumar, E., Rupesh, K., Kavitha, K., Pradeep, K. and Jayakar, B. (2008). Hepatoprotective and antioxidant effect of Pisoniaaculeata $L$ against $\mathrm{CCl}_{4}$ - induced hepatic damage in rats. Sci Pharm., 76: 203-215.

34) Robson, S. C. and Schuppan, D. (2010). Adenosine: tipping the balance towards hepatic steatosis and fibrosis. J Hepatol., 52:941-943.

35) Lazarowski, E. R. and Boucher, R. C. (2009). Purinergic receptors in airway epithelia. Curr Opin Pharmacol., 9:262-267.

36) Junger, W. G. (2011). Immune cell regulation by autocrinepurinergic signaling. Nature Rev Immunol., 11: 201-212.

37) Salmi, M. and Jalkanen, S. (2005). Cell-surface enzymes in control of leukocyte trafficking. Nature Rev Immunol., 5:760-771.

38) Dare, E., Schulte, G., Karovic, O., Hammarberg, C. and Fredholm, B. (2007). Modulation of glial cell functions by adenosine receptors. Physiol Behav., 92:15-20.

39) Sowa, N. A., Taylor-Blake, B. and Zylka, M. J. (2010). Ecto-5'-nucleotidase (CD73) inhibits nociception by hydrolyzing AMP to adenosine in nociceptive circuits. J Neurosci., 30:2235-2244.

40) Zhi, X. L., Wang, Y. J., Zhou, X. R., Yu, J., Jian, R. R., Tang, S. X., Yin, L. H. and Zhou, P. (2010). RNAi-mediated CD73 suppression induces apoptosis and cell-cycle arrest in human breast cancer cells. Cancer Sci., 101:2561-2569.

41) Mikhailov, A., Sokolovskaya, A., Yegutkin, G. G., Amdahl, H., West, A., Yagita, H., Lahesmaa, R., Thompson, L. F., Jalkanen, S., Blokhin, D. and Eriksson, J. E. (2008). CD73 participates in cellular multi-resistance program and protects against TRAIL-induced apoptosis. J Immunol., 181:464475.

42) Chuang, N. N, Newby, A. C. and Luzio, J. P. (1984). Characterization of different molecular forms of 5'-nucleotidase in normal serum and in serum from cholestatic patients and bile-duct-ligated rats. Biochem J., 224:689-695.

43) Peng, Z., Fernandez, P., Wilder, T., Yee, H., Chiriboga, L., Chan, E. S. and Cronstein B. N. (2008). Ecto-5\-nucleotidase (CD73)-mediated extracellular adenosine production plays a critical role in hepatic fibrosis. Nucleosides Nucleotides Nucleic Acids, 27(6):821-824.

44) Thapa, B. R. and Walia, A. (2007). Liver function tests and their interpretation. Indian J. Pediatr., 74: 663-671.

45) Heibatollah, S., Reza, N., Izadpanah, G. and Sohailla, S. (2008). Hepatoprotective effect of Cichoriumintybus on $\mathrm{CCl}_{4}$-induced liver damage in rats. African J Biochem Res., 2:141-144.
46) Latha, T. B., Srikanth, A., Kumar, E. K., Srinivasa, M. S. K., Rao, Y. and Bhavani B. (2009). Comparative hepatoprotective efficacy of Kumaryasava and livfit against carbon tetrachloride induced hepatic damage in rats. Pharmacol., 1:11271134.

47) Yanghee, Y., Soonam, Y., Yoon, Y., Jeongjin, P., Lee, Y., Sunoh, K, Kyung T., Jeongmin, L., HongYon, C. and Woojin J. (2010). In vitro and in vivo hepatoprotective effects of the aqueous extract from Taraxacum officinale (dandelion) root against alcohol-induced oxidative stress. Food and Chemical Toxicology, 48(6): 1632-1637.

48) Friedman, S. (2003). Liver fibrosis-from bench to bedside. J Hepatol., 38(1):38-53.

49) Takahara, T., Zhang, L. P. and Yata Y. (2003). Modulation of matrix metalloproteinase-9 in hepatic stellate cells by three-dimensional type I collagen: its activation and signaling pathway. Hepatol Res., 26:318-326.

50) Tsukada, S., Parsons, C. J. and Rippe, R. A. (2006). Mechanisms of liver fibrosis. Clinica Chimica Acta., 364(1-2):33-60.

51) Kim, H. K., Yang, T. H. and Cho, H. Y. (2009). Antifibrotic effects of green tea on in vitro and in vivo models of liver fibrosis. World J Gastroenterol., 15(41):5200-5205.

52) Esmat, A., Said, M., Soliman, A., El-Masry, K. and Abdel Badiea, E. (2013). Bioactive compounds, antioxidant potential, and hepatoprotective activity of sea cucumber (Holothuriaatra) against thioacetamide intoxication in rats. Nutrition, 29(1):258-267.

53) Nanjappaiah, H. and Shivakumar, H. (2012). Prophylactic and curative effects of Moringa oleifera Lam. pods in $\mathrm{CCl}_{4}$ damaged rat liver. Indian Journal of Natural Products and Resources, 3(4):541-546.

54) Ramos, S. (2007). Effects of dietary flavonoids on appoptotic pathways related to cancer chemoprevention. J. Nutr. Biochem., 18:427-442.

55) Grbović, F., Stanković, M., Ćurčić, M., Đorđević, N., Šeklić, D., Topuzović, M. and Marković, S. (2013). In Vitro cytotoxic activity of Origanum vulgare L. on HCT-116 and MDA-MB-231 cell lines. Plants, 2:371-378.

56) Kandaswami, C., Lee, L. T., Lee, P., Hwang, J., Ke, F., Huang, Y. and Lee M. (2005). The antitumor activities of flavonoids. In Vivo, 19(5):895909.

57) Ĉanadanović, J., Ŝtajner, D., Popović, B. and Anaĉkov, G. (2009). Exploring Equisetum arvense L., Equisetum ramosissimum L. and Equisetum telmateia L. as sources of natural antioxidants. Phytotherapy Research, 23(4):546-550. 